\title{
FESTIVALS AS CULTURAL ACTIVITIES - COMBINATIONS OF ECONOMIC AND SOCIAL BENEFITS
}

\author{
Diana Sava ${ }^{1^{*}}$, Alina Badulescu ${ }^{2}$ \\ ${ }^{1}$ Doctoral School of Economics, Faculty of Economic Sciences, University of Oradea, \\ Oradea, Romania \\ ${ }^{2}$ Department of Economics and Business, Faculty of Economic Sciences, University of \\ Oradea, Oradea, Romania \\ diannasava@yahoo.com, \\ abadulescu@uoradea.ro
}

\begin{abstract}
In the latest years, academics have talked more and more about the creative economy, as a cause of a different classification and division of the economic activities, including in its area all those activities which are based on the human resource, its talent and intellectual capital. The creativity seems to be a too special feature, having its own ways to flourish and to be exploited, so it has to be treated separately from the sectors of manufacture, industry or services. The Romanian culture is transmitted and exploited in various ways, starting with the commercialisation of handicrafts and ending with the organisation of events with artistic or symbolic expression. We will focus on the performing arts, organized as events for different communities. These events appear as leisure activities and have an important social feature because they have the attribute to develop the sense of identity, belonging to the group and social cohesion. These aspects are crucial for the development of a creative habitat or cultural center. The festivals attract people for different reasons; some of them are looking for an environment where to socialise, others come being interested exactly in enjoying the event or the specific goods and services which are offered there. Another type of the festival consumers is represented by the ones who only look for something new to experiment, exploring the unknown, this segment not representing loyal customers, but whatever the reason are, each participant comes for the emotional stimulation offered by the enjoyment of the festival.
\end{abstract}

Keywords: creative economy, cultural economy, cultural activities, festivals.

JEL classification: D12; H42; J24.

\section{Cultural economy}

The concept of creative economy can be understood by approaching its cultural and creative sectors; the literature defines these sectors as "all sectors whose activities are based on cultural values and / or artistic expressions and other creative expressions, regardless of the type of structure carrying them out and the way the structure is financed. These activities include the development, creation, production, dissemination and preservation of goods and services representing cultural, artistic or other creative expressions (...). The cultural and creative sectors include architecture, archives, libraries and museums, artistic crafts, audio-visual (including cinema, television, video and multimedia games), material and immaterial cultural heritage, design, festivals, music, editing, radio and visual arts" (Croitoru, et al., 2016b).

Culture can be considered the long rider for development because it appears as the "recognition of diversity, the respect for otherness and the values of others are essential

\footnotetext{
* Corresponding author: Diana Sava
} 
coordinates of the culture and they can beneficially propagate to other domains" (Croitoru, et al., 2016a). Through culture, the values of the commercialised goods and services are given by tradition, symbolism and artistic expression. Such markets are represented by the Christmas fairs, fairs of other celebrations, events or occasions, as specific festivals or local events.

Aiming to be more accurate about culture, we must mention that it comprises all "practices, goods and ideas that are classified under the generic term of arts (including literature, music, architecture and design, etc., as well as all products of all printed and electronic media), whether used for higher, educational, aesthetic or spiritual purposes, whether used for entertainment purposes. The culture also includes other symbolic products used mainly for leisure and for consumption which are not essential to subsistence (...) but the forms, styles, materials from which they are made, and all other characteristics are also a matter of culture" (Gans in Radu \& Preoteasa, 2012).

Culture is part of the creative economy, and economy is in culture, culture being the drive of the ancient and the new, all in one, for development. Clyde Kluckhohn sees the culture as "a nation's complete way of life; the social inheritance that the individual acquires from his group; a way of thinking, feeling and believing; an abstraction of the behaviour; a shared learning deposit; a set of standardized guidelines towards some recurring problems; educated behaviour; a regulatory normative mechanism of behaviour; a set of adaptation techniques both, to the outside environment, and to other people, as well" (Croitoru, et al., 2016a).

Culture dictates numerous social practices and traditions of a group and it "represents the values of individuals, their own aesthetic and philosophical representations and, at a more collective level, all the way of understanding a people's identity" (ESSnet Report, 2012).

Also culture is considered both cause and effect of the economic development; as a cause of the economic development, the culture creates new jobs and generates incomes. On the other hand, as an effect, culture enhances people's expenditure on culture when the revenues are higher. Moreover, cultural activities are part of the essence of tourist destinations, as local cultural and heritage resources are made available for public through entrepreneurial actions, including cultural entrepreneurs (Badulescu and Badulescu, 2012; Badulescu et al, 2014). There is also a lifestyle entrepreneurial behaviours in the case of cultural entrepreneurs (Badulescu and Badulescu, 2014).

On the other hand, not everyone is so fascinated or optimistic about the creative and cultural economy, the more conservatives seeing the creative economy as transforming culture "into an overwhelmingly economic subject" (Schlesinger, 2016).

\section{Cultural activities: the festivals}

The economic activities included in the cultural economy are various, such as activities specific to the libraries and archives, cultural heritage, audiovisual, visual arts, performing arts and others more. In this paper, some of the performing arts represent our main interest, more exactly those cultural events organized in the form of festivals, events that are becoming more and more important, with particular impacts on marketing and cultural management at the local levels where these events are taking place. Festivals are regarded as events of "public celebration, their theme being attached to a certain symbolism providing emotional stimulation to the participants"(Croitoru, et al. 2016a).

The festivals represent cultural events concentrated in a period of time that "have their primary focus on the development, presentation and/or participation in the arts; have a programme conceived, produced, curated, marketed and presented as an integrated package; and which occur within a defined area/region and within a defined period of time" (Hunyadi et al., 2006). 
Through these events, communities and human behaviors can be known by promoting social inclusion. Festivals are cultural celebration events that differ according to their purpose, consumers, number of participants, duration and place, but all meet the following criteria (Croitoru, et al. 2016a) in order to be called festivals:

- Their main objective is the development, exposition and participation of artistic content activities;

- Being conducted according to a well-defined and promoted schedule;

- Taking place in a well-defined and delimited location and time.

Due to their important role and increasing popularity, the number of entertainment institutions (theatres, philharmonics and symphonic orchestras etc.) has increased in the latest years, also in Romania. Indeed, while during 1990-2012 their number remained almost constant, with very short variations (from 144 in 1990 to 168 in 2012), in 2013 their number soared to 236 , and thein maintaining to 227 in 2016. In the same period, the number of shows and concerts has reported a constant trend, up to a total number of shows od 22,356 in 2016.

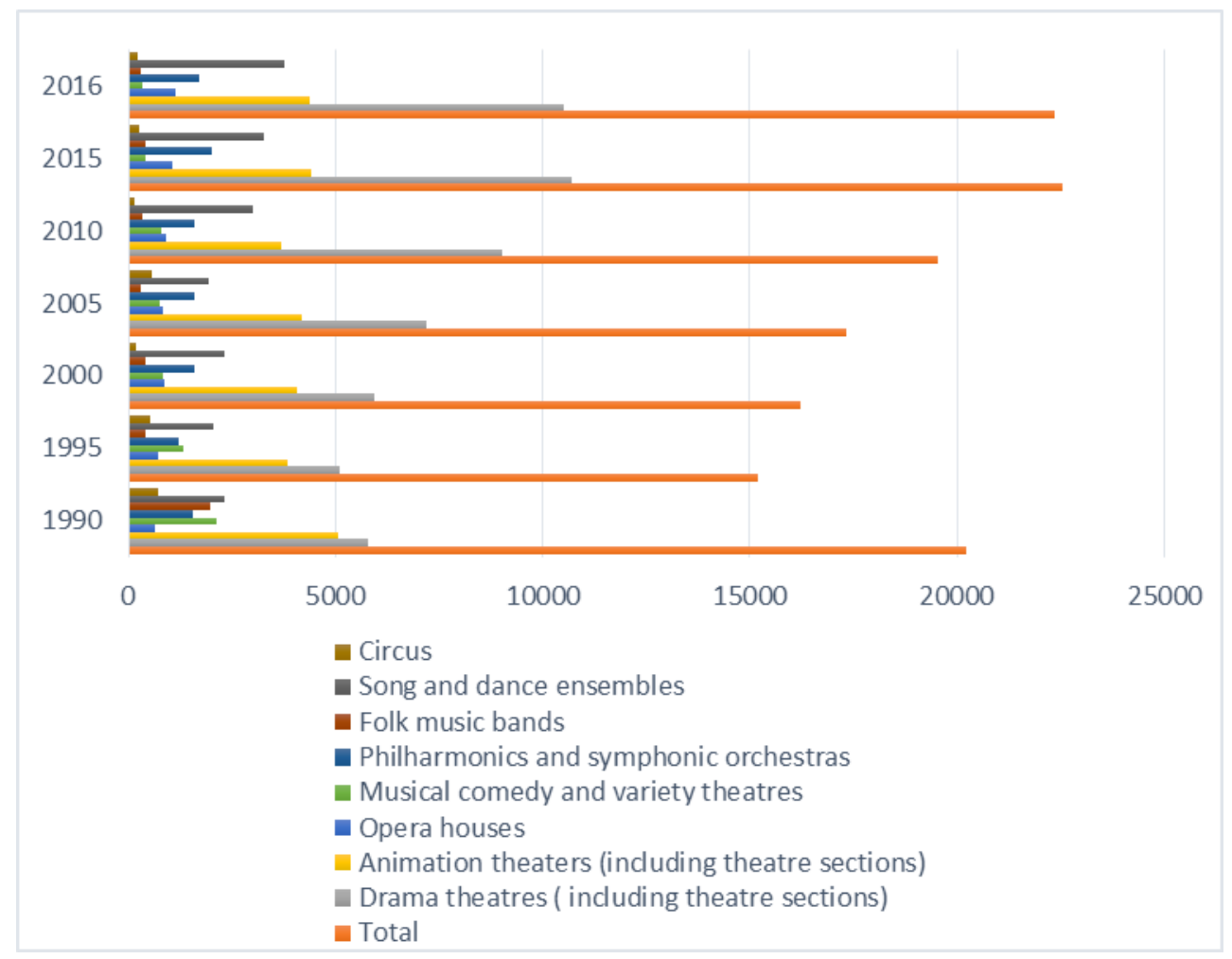

Figure 1: Number of entertainment institutions, by type, selected years Source: own computations based on INSSE data, TEMPO_ART111B

The total audience in Romanian entertainment institutions (theatres, philharmonics and symphonic orchestras etc.) was in 2016 of 5,749,193 persons watching and listening a theatre play or concert (estimated based on tickets sold). From these, only 18 counties and of course Bucharest had an audience of more than 100,000, with Bucharest being from far the best rated. The list of the best performers regarding audience is presented below: 


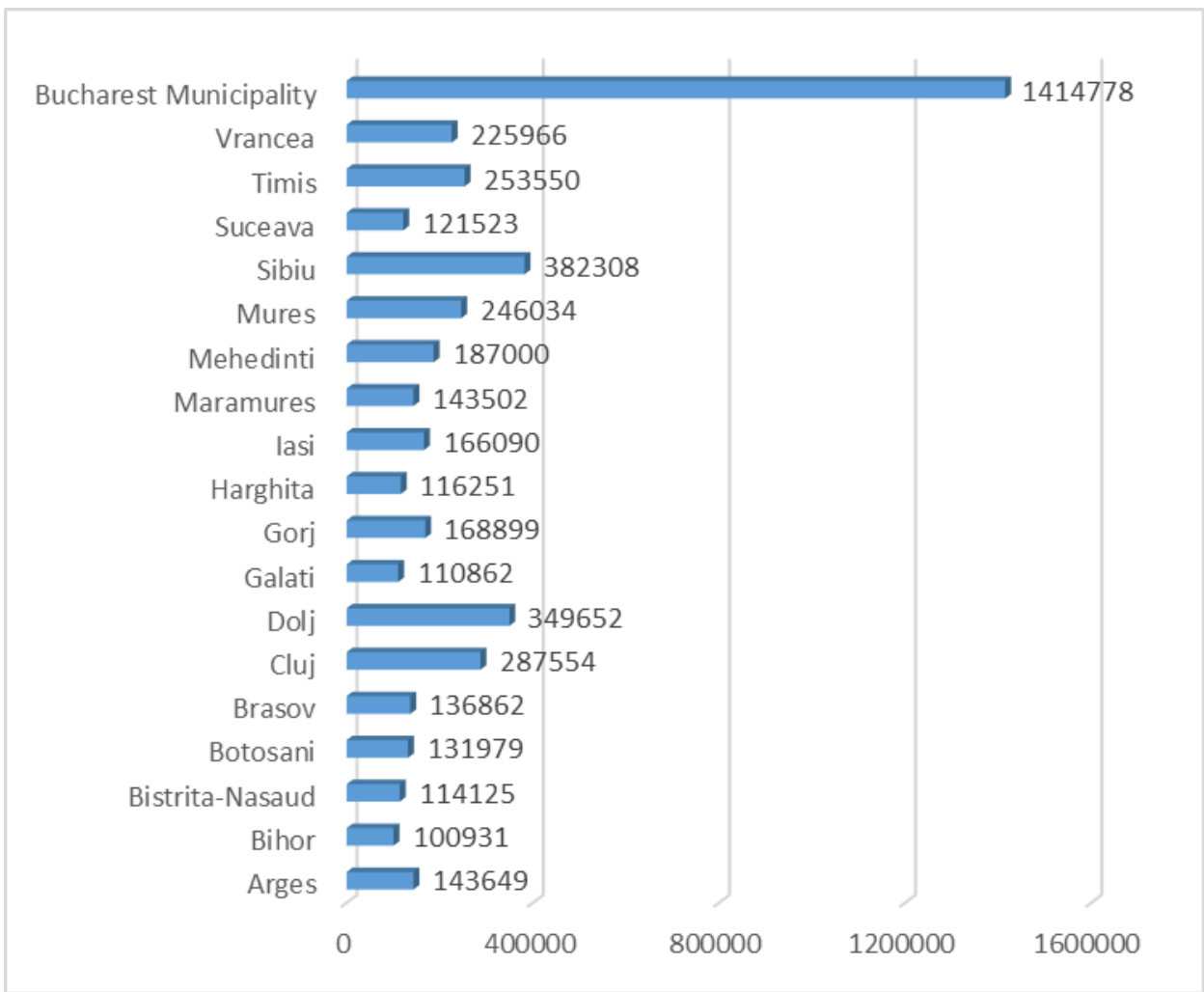

Figure 2: Audience in the entertainment institutions, by counties, 2016:

Source: own computations based on INSSE data, TEMPO_ART112A

As an economic manifestation, the festivals present interest due to the consumption they stimulate, this consumption taking over the sphere of cultural products and services. Of course, the festivals primary aim is to stimulate the cultural consumption; going to various music festivals leads to the purchase of musical products of the performing artists, all sorts of promotional items, for example T-shirts with the favourite artists, but also it leads to future participations at the same festival or similar others.

If we talk about folk music festivals or other certain theme, however, the range of products and services available enlarges from musical products to clothing, handicraft, food and drink, specific to the area and much more. Let's not forget the well-known international examples, such as Rio Carnival, Venice Carnival, Oktoberfest or St. Patrick's Day, festivals that have so far expanded their marketplace that their specific products are also sold outside the space and the specific period of the event.

\section{Roles of the festivals}

Thus, we can see three roles (Croitoru, et al. 2016a) played by festivals, namely cultural, economic, and last but not least, the social role.

The cultural roles comes in the form of "art celebrations and meeting places for the cultural and social elite" (Hunyadi et al., 2006 cited in Croitoru, et al., 2016a:252), but with a growing attraction for the masses, festivals representing places of collective experiences.

Also, festivals are favourable for artistic manifestations for which there is no infrastructure or the demand is generally too low. The festivals bring various opportunities for artists and their creations, managing to promote themselves, but also to get in touch with colleagues from 
other countries or related fields, and to collaborate.

The economic role regards the consumption stimulated by the event; although most festivals require external financing, the revenues from selling tickets fail to cover the costs of organizing them, festivals are an economic success, as they make possible the sale of cultural goods and services in the first place, but also the sale of other types of goods and services demanded by the crowd of consumers attracted by the event.

Social role is highlighted by the effects of organizing such an event on the local people, effects such as local pride and attachment to the community (Hunyadi et al. in Croitoru, et al., 2016a). Moreover, from a social point of view, festivals offer opportunities for development by volunteering in organizing these events and chances for local and amateur artists to promote and make themselves noticed.

\section{Festivals in Romania}

The Romanian culture is transmitted and exploited in various forms, starting with the commercialization of crafts to the organization of concerts, performances and other events on the territory of other countries. The culture of Romania is vast and strongly rooted in some areas of the country, which implies the respect for a multitude of traditions that also have an economic approach. A good example is the organization of weddings, private events that hire artists to conduct various services - interpretation, dance, etc. - thus creating another market, in addition to that of public performances and events, representing additional sources of income for those artists. Aside from festivals, as a place to promote artists, as a market for various cultural goods and services and beyond, festivals are nevertheless created to bring benefits to the society, being a leisure activity.

Strictly from the point of view of the economic benefits of organizing a festival, besides the direct offer at a festival, we must take into account that the magnitude of the event can attract consumers from different areas to increase the consumption of services, such as accommodation and public alimentation in the area where the cultural event takes place. A representative example for Romania is the electronic music festival Untold held in 2015, 2016 and 2017 in Cluj-Napoca. We could say that the debut of Untold Festival is also evident in the figures of turnover presented in the following table, during the years 2010-2014 the turnover in this sector had a constant positive evolution, but from 2015 there was a high increase, as it can be seen.

Table 1: Turnover of the performing arts (million RON)

\begin{tabular}{|c|c|c|c|c|c|c|c|}
\hline & 2010 & 2011 & 2012 & 2013 & 2014 & 2015 & 2016 \\
\hline $\begin{array}{l}\text { Performing } \\
\text { arts }\end{array}$ & $\begin{array}{r}448176 \\
739\end{array}$ & $\begin{array}{r}561152 \\
457\end{array}$ & $\begin{array}{r}655361 \\
877\end{array}$ & $\begin{array}{r}694539 \\
610\end{array}$ & $\begin{array}{r}761653 \\
041\end{array}$ & $\begin{array}{r}1028738 \\
680\end{array}$ & $\begin{array}{r}1384728 \\
825\end{array}$ \\
\hline
\end{tabular}

Source: designed by the authors using information from Borg Design

Beyond the general economic and social benefits of a festival, Untold assumed its social role through a method of promotion, namely through a blood donation campaign, offering free tickets for blood donors from Cluj-Napoca and Bucharest.

But Cluj-Napoca is also recognized due to another international festival, the Electric Castle Festival. Its first edition was held in 2013 and since then every year it was organized somewhere between June and July. This is also an electronic music festival, but a smaller one than Untold. Although the two festivals seem to be in competition, the two are two separate events and they work together to attract participants during the summer months, taking place with a sufficient pause between them in order to attract both participants.

Another important festival in Romania takes place, for example, in Timisoara, the PLAI 
Festival, an event that proclaims to celebrate diversity and multiculturalism, being organized since 2006. PLAl is a music festival that also attracts singers from all corners of the world and various creative activities take place under the auspices of several non-profit organizations. This festival also has a quite important social dimension.

We can also remember lasi as there are many fashion events, the Art East Festival of lasi and the International Fashion Festival Kasta Morrely Fashion Week, just some festivals that outline lasi as a fashion pole in Romania, but there are also festivals on other themes (music, film, culinary, literature, etc.).

There is even a festival of creative industries taking place in Bucharest; the Creative East festival aims to sustain creativity, create links between the creative class members, bringing together speakers, economic operators and sponsors in order to explore "how design, fashion, art and technology can shape our cities and boost the quality of our urban life. Keen on helping creative people reach their goals, Creative Est will be the ultimate destination for networking and inspiration, hosting workshops, interactive talks and showcases" (Creative Est, 2017).

Festivals are held all around the country, but the most favorable areas remain the large, developed cities with high potential in tourism and culture, such as Bucharest, Timisoara, Cluj-Napoca, lasi, etc.

Figure 3 confirms the importance of these cities for organizing festivals; the capital is the main scene for these activities, but we notice that Timisoara is following Bucharest, then Cluj-Napoca, Brasov, Pitesti, Sibiu and Constanta. There are other areas of interest, but there is also an interesting area linking the capital with Braşov, Ploieşti and Prahova Valley.

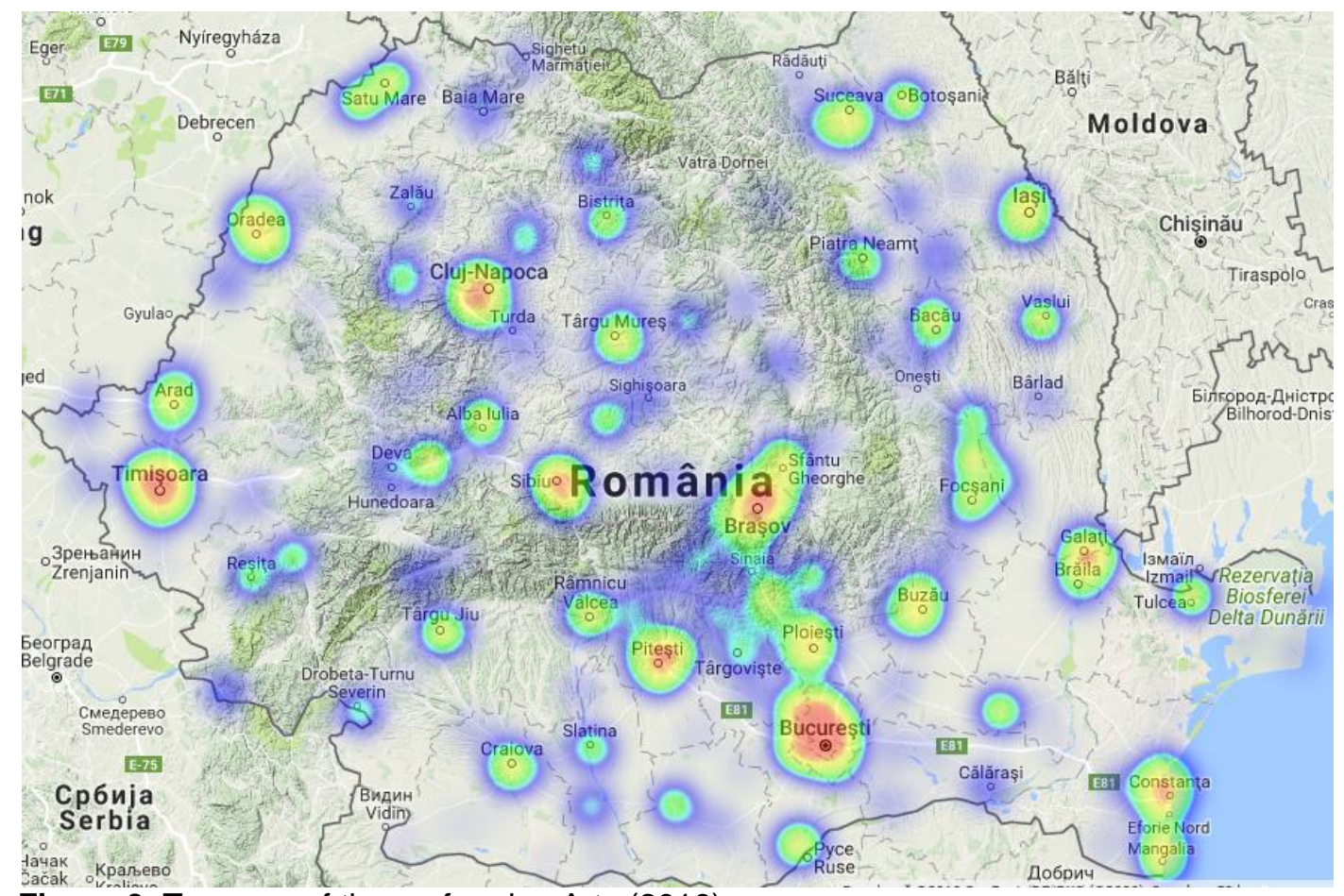

Figure 3. Turnover of the performing Arts (2016)

Source:

Borg

Design

from

https://www.listafirme.ro/heatmap.asp?tip=cifra\&contrast=50\#heatmapArea 
A study conducted in Romania by the National Institute for Cultural Research and Formation (Croitoru et al., 2016), regarding the cultural consumption of the population in 2015, highlighted some preferences in the matter of festivals. The conclusion was that the most attractive festivals were those with free access, organised as local celebrations. The results of the study are presented in Figure 4.

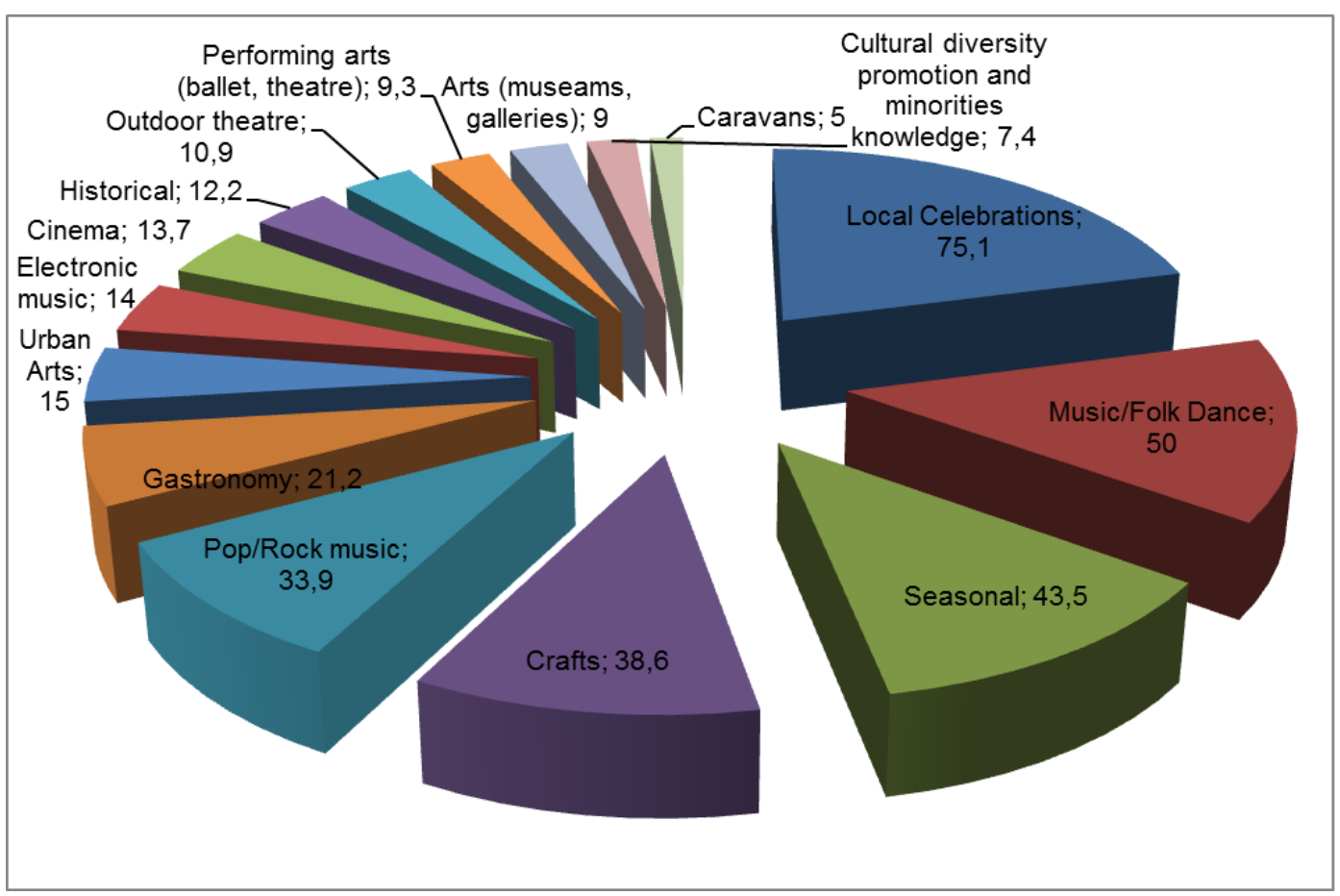

Figure 4: Festival attendance of the population of Romania in 2015

Source: realised by the author based on information from Croitoru, et al., 2016. Barometrul de consum cultural 2015. Preferințe, practici și tendințe.

Analysing the values, we can notice that the local celebrations, such as beer's festival or wine's festival, are the most attractive, being followed by music and folk dance festival, and also the seasonal festival present a lot of interest for the public. Generally, the local celebrations, folk dance and seasonal festival are free access, being funded by the local authorities and several sponsors, so we can think that the free access increased the attractiveness of these events. After the price level to access these activities, there comes the idea of regularity of the event and the people's habits. These are pretty general festivals even if there is a particular theme, and that's another reason of their attractiveness.

Festivals attract people for different reasons; some are looking for an environment in which to socialize, usually with people who are close to them, others are looking exactly for the specifics of the organized event, while another type of spectators are the ones who just experience, explore the unknown, this segment not representing a faithful clientele.

Regarding strictly the economic benefits of organizing a festival, besides the specific goods and services offered directly to the participants, we must take into account that the magnitude of the event can attract persons from different areas and so, to increase the consumption of accommodation and restaurant services in the area where they come to attend to the cultural event. 


\section{In conclusion}

Many times when the concept of the creative economy is discussed, there comes to light also the concept of cultural economy. The area of the cultural economy is smaller because it is part of the creative economy and what exactly we can say about it, according to Allen Scott, is that the "cultural economy comprises all those sectors in modern capitalism that cater to consumer demands for amusement, ornamentation, self-affirmation, social display and so on" (UNESCO, 2013).

Long time ago, the culture framed the high society, and nowadays, the social and economic developed countries. Apart of all these social aspects of the culture, culture through its specific activities, carrying artistic and symbolic expressiveness, produces some important economic effects, such as creating new jobs and generating incomes.

Considering the festivals, as opportunities to promote artists, also as a market for various cultural goods and services, and not only cultural, festivals are nevertheless created to bring a benefit to society, being a leisure activity. On the other hand, festivals offer rare, perhaps even unique experiences, and also they make accessible different goods and services that would not normally be available at prices that are too high, this being possible because of the joint efforts of various public and private entities.

Analysing the Romanian festival attendance, it seems that celebrations and local events attract the most participants, primarily due to their free access and also due to their regularity and the habit of the participants. Following these types of events, folk music and seasonal festivals such as the beer festival, wine, etc. are following in the populations' preferences.

\section{References}

Badulescu, A. and Badulescu, D., 2012. "Entrepreneurship and Local Resources". In book: Tourism Enterprises and the Sustainability Agenda across Europe (ed. Leslie David), London, Ashgate Publishing.

Badulescu, A., Badulescu, D., Bac, D. and Sipos-Gug, S., 2014. "Attitudes and intentions of business master students towards sustainable tourism and entrepreneurship". Amfiteatru Economic Journal. Volume 16, Special issue No. 8, pp. 1110-1124.

Badulescu, A. and Badulescu, D. 2014. "Is There Evidence of a European Lifestyle Entrepreneur in Tourism?". The Annals of the University of Oradea, 23(1), pp. 231-242.

Croitoru, C., Becuț, A., Ceobanu, I., Crăciun, A., Dragomir, A., luga, L., Mateescu, O., Manea, M., Oană, I., Pălici, B. and Voicu, Ș., 2016a. "Barometrul de consum cultural 2015. Preferințe, practici și tendințe", p. 8, 9, 252, 257-259, 271 [pdf] Available at: $<$ http://www.culturadata.ro/wp-content/uploads/2016/09/Barometrul-de-Consum-Cultural-2 015.pdf $>$ [Accessed 30 January 2018]

Croitoru C., Cojanu V., Mucică D. and Becuț A., 2016b. „Cartea albă pentru activarea potențialului economic al sectoarelor culturale și creative din România", p.16 [pdf] Available at: <http://www.culturadata.ro/wp-content/uploads/2017/04/2016_Cartea_Alba_RO.pdf> [Accessed 15 January 2018]

ESSnet - CULTURE European Statistical System Network on Culture - Final Report (2012), p. 41 [pdf], Available at: <http://ec.europa.eu/culture/library/reports/ess-net-report en.pdf> [Accessed 29 January 2018]

Hunyadi, Z., Inkei, P., Szabo, J. Z., 2006. Festival - world Summary report. National survey on festivals in Hungary including deliberations on public funding, evaluation and monitoring, p. 8, [pdf] Available at: http://www.budobs.org/pdf/Festival en.pdf [Accessed 09 May 2018] Radu, R., Preoteasa, M., 2012. Economia mass-media, Polirom, București, 2012, p. 10 Schlesinger, P., 2016. The creative economy: invention of a global orthodoxy, Innovation-The European Journal Of Social Science Research, [e-journal] (30), available through: $\quad$ Enformation Library website $<$ http://apps.webofknowledge.com.am.e-nformation.ro/full record.do?product=WOS\&searc 
h mode $=$ GeneralSearch\&qid $=5 \&$ SID $=2$ ENVMQvrhsBTkh1 $\mathrm{eJtB} \&$ page $=3 \&$ doc $=27>$ Access ed 27 January 2018]

UNCTAD, Creative economy report 2010, p. 10, [pdf] Available at: <http://unctad.org/en/Docs/ditctab20103 en.pdf>[Accessed 21 January 2018]

UNESCO, Creative Economy Report 2013 Special Edition - Widening local development pathways,

p. 24 , [pdf] available http://academy.ssc.undp.org/GSSDAcademy/Upload/CER13 Report web optimized.pdf [Accessed 28 January 2018]

Borg Design, 2017. Turnover of the performing Arts 2016. [online] Available at: $<$ https://membri.listafirme.ro/heatmap.asp?tip=cifra\&contrast=50\#heatmapArea $>$

[Accessed 23 January 2018].

Creative Est Festival, 2017. About us. [online] Available at: <http://creativeest.ro/> [Accessed 19 January 2018]

Electric Castle Festival, 2017. History. [online] Available at: $<$ https://electriccastle.ro/history $>$ [Accessed 19 January 2018]

Plai Festival, 2017. Despre. [online] Available at: <http://www.plai.ro/despre/> [Accessed 19 January 2018]

\section{Bio-note}

Diana Sava is PhD student at the Doctoral School of Economic Sciences, University of Oradea. Her research interests include economics of cultural and creative industries.

Alina Badulescu is professor of Economics, member of the Department of Economics and Business and PhD supervisor at the Doctoral School of Economics, University of Oradea. Her research interests include economics of services and tourism and economics of entrepreneurship. 